Original Research Paper

\title{
Characterization of Lignocellulolytic Bacteria from Gut of Termite (Isoptera: Rhinotermitidae and Termitidae)
}

\author{
Putri Dwi Mulyani ${ }^{1}$, Muhammad Rizky Ulil Albab ${ }^{1}$, Yekti Asih Purwestri ${ }^{1,2^{*}}$ \\ ${ }^{1}$ Biochemistry Laboratory, Tropical Biology Department, Faculty of Biology, Universitas Gadjah \\ Mada, Jalan Teknika Selatan, Sekip Utara, Yogyakarta 55281, Indonesia \\ ${ }^{2}$ Research Center for Biotechnology, Universitas Gadjah Mada, Jalan Teknika Utara, Barek, Depok, \\ Sleman, Yogyakarta, Indonesia
}

\begin{abstract}
Article History
Received : June $22^{\text {th }}, 2021$

Revised : June $30^{\text {th }}, 2021$

Accepted : July $12^{\text {th }}, 2021$

Published : July $17^{\text {th }}, 2021$

*Corresponding Author:

Yekti Asih Purwestri,

Research Center for

Biotechnology, Universitas

Gadjah Mada, Jalan Teknika

Utara, Barek, Depok, Sleman,

Yogyakarta, Indonesia

Email: yekti@ugm.ac.id
\end{abstract}

\begin{abstract}
A total of 10 bacterial isolates have been isolated from the gut of termites (Isoptera: Rhinotermitidae and Termitidae) and are known to have the ability to produce lignocellulolytic enzymes consisting of cellulase, laccase, and lignin peroxidase. The enzymatic ability allows these bacteria to be used as a source of new enzymes in the industrial world. However, further research on the character of bacteria to support identification has not been carried out. This study aims to characterize lignocellulolytic bacteria in the gut of termites morphologically and biochemically. Morphological observations were carried out including colony shape, colony edge, colony color, growth type, bacterial cell shape, and gram staining. Meanwhile, the biochemical characterization carried out included glucose fermentation test, indole formation, starch hydrolysis, catalase test, and nitrate reduction. The results showed that ten isolates of lignocellulolytic bacteria from the gut of termites (Isoptera: Rhinotermitidae and Termitidae) grew facultatively anaerobic, had almost similar morphological characters, with colony shapes including irregular and filamentous, colony edges in the form of lobate, undulate, and filamentous, and coloration. Colonies are white to yellowish white. The result of gram staining showed that most of the bacteria were gram positive bacteria with coccus and bacillus shaped bacterial cells. Biochemical analysis showed that these bacteria have the ability to ferment glucose, hydrolyze starch, reduce hydrogen peroxide $\left(\mathrm{H}_{2} \mathrm{O}_{2} \quad 30 \%\right)$ and reduce nitrate.
\end{abstract}

Keywords: Lignocellulolytic bacteria, termite gut, morphology, biochemical characterization

\section{Pendahuluan}

Lignoselulosa merupakan salah satu sumberdaya alam yang paling melimpah di dunia sehingga berpotensi besar untuk menghasilkan energi terbarukan, khususnya sebagai bahan bakar nabati (Zhou et al., 2018) tetapi pemanfaatan lignoselulosa seringkali kurang optimal karena kandungan penyusunnya yang sulit didegradasi. Lignoselulosa terdiri atas kompleks selulosa, hemiselulosa, dan lignin (Nasehi et al., 2014). Rayap merupakan salah satu serangga yang mengonsumsi serasah kayu dan diketahui mampu mencerna lignoselulosa pada kayu. Kemampuan rayap dalam mendegradasi berbagai komponen penyusun kayu disebabkan karena adanya simbiosis dengan mikroorganisme pada saluran pencernaan rayap. Mikroorganisme ini diketahui mampu memproduksi berbagai enzim untuk membantu degradasi lignoselulosa yang dikonsumsi oleh rayap (Masai et al., 2003; Molina-Guijarro et al., 2009), seperti selulase, xylanase (Lazuka et al., 2018), lakase, lignin peroxidase (Brune, 2014), amilase, protease (Lima et al., 2014), dan pektinase (Sakolvaree \& Deevonga, 2016). Hal ini membuktikan bahwa bakteri pada rayap dapat dijadikan sebagai sumber alami baru untuk memproduksi enzim.

$$
\text { Penelitian mengenai bakteri }
$$

lignoselulolitik potensial dari rayap di 
Indonesia belum banyak dilakukan. Penelitian serta analisis mengenai aspek mikrobiologis seperti karakter koloni, karakter sel bakteri, serta aktivitas biokimiawi bakteri menjadi sangat penting dalam mendukung identifikasi bakteri potensial penghasil enzim lignoselulolitik dari pencernaan rayap. Penelitian dan analisis lebih lanjut sangat penting dilakukan untuk memperoleh bakteri potensial baru sebagai sumber enzim yang diharapkan mampu dimanfaatkan sebagai salah satu alternatif dalam proses degradasi lignoselulosa. Penelitian ini bertujuan untuk: melakukan karakterisasi morfologi koloni bakteri lignoselulolitik rayap; menganalisis karakter morfologi sel berupa bentuk sel dan sifat gram, dan menganalisis karakter biokimiawi bakteri lignoselulolitik saluran pencernaan rayap (Isoptera: Rhinotermitidae dan Termitidae) yang telah diisolasi dan diuji kemampuan lignoselulolitiknya pada penelitian sebelumnya.

\section{Bahan dan Metode}

Penelitian ini menggunakan isolat bakteri lignoselulolitik potensial yang telah diisolasi dari pencernaan rayap famili Rhinotermitidae dan Termitidae oleh Mulyani et al., (2021). Beberapa bahan kimia lain yang digunakan dalam penelitian ini antara lain: medium Nutrient Agar (NA), Nutrient Borth (NB), medium tripton cair, kristal violet (gram A), Larutan lugol iodine (gram B), alkohol 95\% (gram C), safranin (gram D), reagen Erlich, glukosa, pati, larutan iodin, ether, $\mathrm{H}_{2} \mathrm{O}_{2} 30 \%$, asam sulfanilat (larutan A), larutan alfa naftilamin (larutan B), dan aquades.

\section{Rejuvenasi Isolat Bakteri}

Sepuluh isolat bakteri potensial penghasil enzim lignoselulolitik telah diisolasi dari pencernaan rayap famili Rhinotermitidae dan Termitidae (Mulyani et al., 2021). Dua isolat bakteri A dan D berasal dari saluran pencernaan rayap anggota famili Rhinotermitidae, sementara delapan isolat bakteri lainnya, yakni 7, 11.2, 16, 17, 20, 22, 46, dan 75 diisolasi dari saluran pencernaan rayap anggota famili Termitidae. Seluruh bakteri selanjutnya disubkultur secara streak pada medium NA dan diinkubasi selama
48 jam pada suhu $37^{\circ} \mathrm{C}$ dalam inkubator. Kultur murni dari keseluruhan isolat selanjutnya digunakan sebagai inokulum uji dalam tahap karakterisasi morfologi dan biokimia.

\section{Karakterisasi Morfologi Koloni}

Seluruh isolat ditumbuhkan pada medium NA dalam cawan petri dengan menggunakan metode titik dan diinkubasi selama 24 jam pada suhu $37^{\circ} \mathrm{C}$. Pengamatan bentuk pertumbuhan, dan karakterisasi morfologi isolat secara makroskopik maupun mikroskopik yang meliputi, bentuk koloni bakteri, bentuk tepi koloni, warna koloni, bentuk sel, serta jenis gram bakteri. Penentuan jenis pertumbuhan bakteri dilakukan dengan menumbuhkan bakteri pada medium NB sebanyak $5 \mathrm{~mL}$ di dalam tabung reaksi secara aseptis. Pertumbuhan sel bakteri di dasar tabung setelah inkubasi menunjukkan bahwa bakteri memiliki sifat anaerobik, pertumbuhan pada permukaan medium menunjukkan bakteri bersifat aerobik, sementara pertumbuhan bakteri mendekati permukaan medium menunjukkan bakteri bersifat fakultatif anaerob.

\section{Pengamatan Bentuk Sel dan Sifat Gram Bakteri}

Pewarnaan gram dilakukan pada kultur bakteri umur 24 jam yang ditumbuhkan dalam media NA dengan mengikuti metode Hucker (1921) dalam Pukhrambam (2019). Proses pengecatan ini dilakukan dengan menggunakan larutan kristal violet sebagai gram A yang berfungsi sebagai cat primer sehingga memberi warna ungu pada bakteri target, larutan lugol iodine sebagai gram B yang berfungsi untuk memperkuat warna dari gram A dan menyebabkan bakteri sampel bewarna coklat, alkohol 95\% sebagai gram $\mathrm{C}$ yang berperan dalam melunturkan cat sebelumnya, dan safranin sebagai gram D yang memberikan warna merah pada bakteri. Isolat bakteri yang sudah diwarnai selanjutnya diamati dengan mikroskop pada perbesaran 100x. Bakteri dengan warna biru keunguan adalah bakteri Gram positif, sementara bakteri yang tampak berwarna merah muda adalah bakteri Gram negatif.

\section{Karakterisasi Biokimia}

a. Fermentasi Glukosa 
Uji ini dilakukan mengikuti metode Mannan et al., (2017) dengan modifikasi. Sepuluh isolat bakteri saluran pencernaan rayap masingmasing ditumbuhkan pada $5 \mathrm{~mL}$ medium glukosa secara aseptis. Selanjutnya kultur diinkubasi selama 48 jam pada suhu $37^{\circ} \mathrm{C}$. Hasil positif ditunjukkan dengan adanya perubahan warna medium menjadi kuning dan terbentuknya gas.

b. Hidrolisis Pati

Uji kemampuan hidrolisis pati mengacu pada metode dari Suryono et al., (2019). Isolat bakteri ditumbuhkan pada medium NA yang diperkaya dengan pati. Selanjutnya, medium dituang ke cawan petri dan dibiarkan menjendal. Sepuluh isolat bakteri pencernaan rayap diinokulasi pada masing-masing cawan petri dengan metode streak plate secara aseptis dan diinkubasi selama 48 jam pada suhu $37^{\circ} \mathrm{C}$. Kultur bakteri selanjutnya ditetesi dengan larutan iod. Aktivitas hidrolisis pati ditunjukkan dengan adanya zona jernih disekitar koloni bakteri.

c. Pembentukan Indol

Isolat bakteri ditumbuhkan dalam $5 \mathrm{~mL}$ medium tripton cair pada tabung reaksi. Selanjutnya kultur diinkubasi selama 48 jam pada suhu $37^{\circ} \mathrm{C}$, ditambahkan $1 \mathrm{ml}$ larutan ether dan digojok hingga lapisan ether terbentuk pada bagian atas. Kemudian, sampel ditetesi reagen erlich melalui tepi tabung. Hasil uji positif ditandai dengan terbentuknya cicin berwarna merah (Hussain et al., 2013).

d. Uji Katalase

Uji katalase mengacu pada metode Begum et al., (2017). Isolat bakteri pencernaan rayap ditumbuhkan pada medium NA dan diinkubasi selama 24 jam. Selanjutnya, secara aseptis 10 isolat bakteri pencernaan rayap diinokulasi menggunakan jarum ose pada gelas benda. Kultur bakteri kemudian ditetesi $\mathrm{H}_{2} \mathrm{O}_{2} \quad 30 \%$.
Aktivitas katalase ditandai dengan terbentuknya gelembung busa.

e. Reduksi Nitrat

Pengujian reduksi nitrat oleh bakteri dilakukan mengikuti metode Hussain et al., (2013). Isolat bakteri ditumbuhkan pada $5 \mathrm{~mL}$ medium cair yang mengandung nitrat pada tabung reaksi selanjutnya bakteri diinkubasi pada suhu $37^{\circ} \mathrm{C}$ selama 48 jam. Pada kultur bakteri sebanyak $1 \mathrm{~mL}$ larutan asam sulfanilat (larutan A) dan $1 \mathrm{ml}$ larutan alfa naftilamin (larutan B) ditambahkan. Adanya perubahan warna menjadi kemerahan menunjukkan adanya aktivitas reduksi nitrat.

\section{Hasil dan Pembahasan}

\section{Karakterisasi Morfologi Koloni}

Berdasarkan hasil pengamatan pertumbuhan bakteri lignoselulolitik saluran pencernaan rayap pada medium NB, diketahui bahwa sepuluh bakteri saluran pencernaan rayap menunjukkan pertumbuhan yang bersifat fakultatif anaerob. Bakteri dengan jenis pertumbuhan fakultatif anaerob menunjukkan kemampuan adaptasi metabolisme dan pertumbuhan di bawah kondisi dengan atau tanpa oksigen, tetapi cenderung pada kondisi aerobik (Stieglmeier et al., 2009). Hasil ini didukung oleh penelitian Wenzel et al., (2002) yang menemukan bahwa bakteri saluran pencernaan rayap memiliki karakteristik bersifat fakultatif anaerob. Beberapa bakteri fakultatif anaerob seperti Pseudomonas juga diketahui berperan dalam memetabolisme aromatik dan lignoaromatik (Taylor, 1983; Liang et al., 2014; Auer et al., 2017). Secara makroskopis, koloni bakteri lignoselulolitik saluran pencernaan rayap menunjukkan karakter morfologi meliputi bentuk yang irregular dan filamentous, tepi koloni berupa lobate, undulate, dan filamentous, serta warna koloni berupa putih sampai putih kekuningan (Tabel 1).

\section{Pengamatan Bentuk Sel dan Sifat Gram Bakteri}

Dari hasil pengamatan secara mikroskopis (Tabel 2), diketahui bahwa bakteri 
A, D, dan 11.2 memiliki sel berbentuk basil, sementara isolat bakteri 7, 16, 17, 20, 22, 46, dan 75 memiliki sel berbentuk coccus. Kedua jenis

Tabel 1. Karakteristik koloni bakteri lignoselulolitik pencernaan rayap (Isoptera: Rhinotermitidae dan Termitidae)

\begin{tabular}{|c|c|c|c|c|c|}
\hline \multirow{2}{*}{ No. } & \multirow{2}{*}{$\begin{array}{l}\text { Kode } \\
\text { Isolat }\end{array}$} & \multicolumn{4}{|c|}{ Karakteristik Koloni } \\
\cline { 3 - 6 } & Bentuk Koloni & Tepi Koloni & Warna Koloni & Jenis Pertumbuhan \\
\hline $\mathbf{1 .}$ & A & Irregular & Lobate & Putih kekuningan & Fakultatif anaerob \\
\hline $\mathbf{2 .}$ & D & Irregular & Lobate & Putih kekuningan & Fakultatif anaerob \\
\hline $\mathbf{3 .}$ & 7 & Irregular & Undulate & Putih & Fakultatif anaerob \\
\hline $\mathbf{4 .}$ & 11.2 & Filamentous & Filamentous & Putih kekuningan & Fakultatif anaerob \\
\hline $\mathbf{5 .}$ & 16 & Irregular & Undulate & Putih kekuningan & Fakultatif anaerob \\
\hline $\mathbf{6 .}$ & 17 & Irregular & Undulate & Putih & Fakultatif anaerob \\
\hline $\mathbf{7 .}$ & 20 & Irregular & Undulate & Putih & Fakultatif anaerob \\
\hline $\mathbf{8 .}$ & 22 & Irregular & Undulate & Putih & Fakultatif anaerob \\
\hline $\mathbf{9 .}$ & 46 & Irregular & Undulate & Putih & Fakultatif anaerob \\
\hline $\mathbf{1 0 .}$ & 75 & Irregular & Undulate & Putih kekuningan & Fakultatif anaerob \\
\hline
\end{tabular}

bakteri ini sangat umum ditemukan pada saluran pencernaan rayap. Berdasarkan hasil pengecatan gram, bakteri A, D, 7, 17, 20, 22, 46, dan 75 menunjukkan hasil uji gram sebagai bakteri gram positif sementara 11.2 dan 16 sebagai bakteri gram negatif (Gambar 1).

Perbedaan jenis bakteri gram posfitif dan negatif didasarkan pada lapisan peptidoglikan yang menyebabkan adanya perbedaan sifat kimia dan fisik dinding selnya. Pada bakteri gram positif, dinding sel bakteri memiliki lapisan peptidoglikan yang tebal sehingga mampu mempertahankan warna biru keunguan dari kristal violet walaupun dilakukan beberapa kali pencucian dengan alkohol. Sementara pada bakteri gram negatif, lapisan peptidoglikannya sangat tipis dan akan larut ketika alkohol ditambahkan. Hal ini menyebabkan sel bakteri gram negatif kehilangan warna awalnya dari pewarnaan primer (Kristal violet) dan hanya menyisakan warna merah di akhir pengecatan.

Umumnya, bakteri dengan bentuk bacil akan menunjukkan hasil pengecatan gram positif, sementara bakteri dengan bentuk coccus lebih beragam. Hal ini sesuai dengan hasil penelitian Ferbiyanto et al., (2015) yang juga menemunkan bakteri gram positif berbentuk bacil pada isolat bakteri pencernaan rayap. Akan tetapi beberapa strain bakteri bacil tertentu dapat menunjukkan sifat gram negatif seperti yang terjadi pada isolat bakteri 11.2 yang justru menunjukkan warna kemerahan yang mengindikasikan jenis gram negatif. Data ini sesuai dengan penelitian Devaraj dan Kesti (2019) yang juga berhasil mengisolasi bakteri gram negatif berbentuk bacil dari pencernaan rayap.

Tabel 2. Karakteristik isolat bakteri lignoselulolitik pencernaan rayap (Isoptera: Rhinotermitidae dan Termitidae)

\begin{tabular}{|c|c|c|c|}
\hline No. & Kode isolat & Bentuk sel & Uji gram \\
\hline $\mathbf{1 .}$ & A & Bacil & + \\
\hline $\mathbf{2 .}$ & D & Bacil & + \\
\hline $\mathbf{3 .}$ & 7 & Coccus & + \\
\hline $\mathbf{4 .}$ & 11.2 & Bacil & - \\
\hline $\mathbf{5 .}$ & 16 & Coccus & - \\
\hline $\mathbf{6 .}$ & 17 & Coccus & + \\
\hline
\end{tabular}




\begin{tabular}{|c|c|c|c|}
\hline $\mathbf{7 .}$ & 20 & Coccus & + \\
\hline $\mathbf{8 .}$ & 22 & Coccus & + \\
\hline $\mathbf{9 .}$ & 46 & Coccus & + \\
\hline $\mathbf{1 0 .}$ & 75 & Coccus & + \\
\hline
\end{tabular}

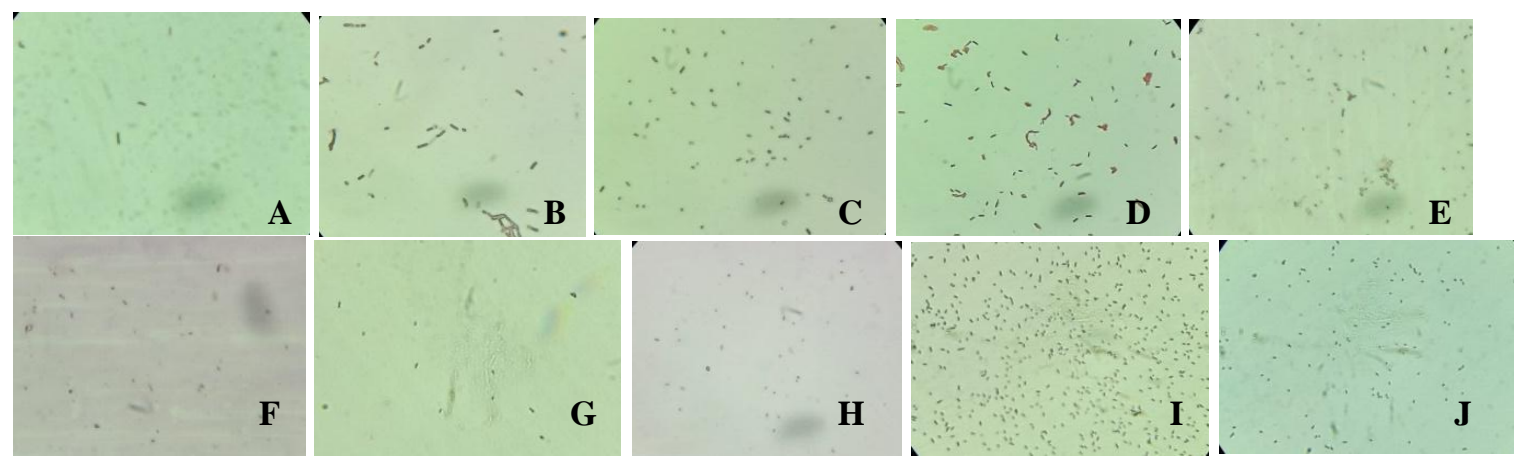

Gambar 1. Pewarnaan gram isolat bakteri pencernaan rayap pada perbesaran 100x. (A) isolat A, (B) isolat D, (C) isolat 7, (D) isolat 11.2, (E) isolat 16, (F) isolat 17, (G) isolat 20, (H) isolat 22, (I) isolat 46, (J) isolat 75

\section{Karakterisasi Biokimia}

Karakterisasi biokimia diperlukan untuk mengidentifikasi spesies bakteri lignoselulolitik pencernaan rayap berdasarkan perbedaan aktivitas biokimia bakteri.

a. Fermentasi Glukosa

Uji fermentasi glukosa bertujuan untuk melihat kemampuan isolat bakteri lignoselulolitik perncernaan rayap dalam memfermentasi glukosa. Berdasarkan hasil yang diperoleh, seluruh isolat bakteri pencernaan rayap menunjukkan kemampuan dalam memfermentasi glukosa, yang ditandai dengan adanya perubahan warna medium dari merah menjadi kuning. Perubahan warna ini menunjukkan sudah terjadinya pembentukan asam. Semakin kuning medium, mengindikasikan bahwa medium semakin asam. Data menunjjukkan bahwa isolat bakteri yang memiliki kemampuan fermentasi tertimggi adalah isolat $\mathrm{A}, \mathrm{D}, 16,17$, dan 75, diikuti olehisolat 11.2 , 22, dan 46, serta yang paling rendah aktivitas fermentasi glukosanya adalah isolat T dan 20 (Tabel 3).

\section{b. Hidrolisis Pati}

Uji hidrolisis pati bertujuan untuk melihat kemampuan bakteri dalam menghidrolisi pati. Terbentuknya zona bening di sekitar koloni setelah pemberian larutan iod menunjukkan bahwa bakteri memiliki kemampuan dalam menghidrolisis pati. Larutan iod akan berikatan dengan amilum sehingga berwarna biru, sementara pada pati atau amilum yang sudah dihidrolisis oleh bakteri tidak lagi dapat diwarnai oleh iod. Hal ini lah yang menyebabkan terbentuknya zona bening disekitar koloni.

Berdasarkan hasil penelitian, didapatkan data bahwa seluruh isolat bakteri lignolitik saluran pencernaan rayap mampu menghidrolisis pati ditandai dengan terbentuknya zona bening di sekitar koloni. Kemampuan hidrolisis pati dari yang paling tinggi adalah $\mathrm{A}$ dan $\mathrm{D}$, diikuti oleh 7, 16, 17, 22 , 46, dan 75 , serta yang peling rendah adalah 11.2 dan 20 (Tabel 3). Data ini juga menunjukkan bahwa bakteri ini memiliki potensi dalam menghasilkan enzim $\alpha$ amilase yang berperan dalam proses hidrolisis pati/amilum menjadi sakarida yang lebih sederhana lagi seperti maltosa dan glukosa. Hal ini mendukung hasil penelitian Lima et al., (2014) yang melaporkan bahwa bakteri saluran pencernaan rayap memiliki kemampuan dalam mendegradasi amilum dengan menproduksi $\alpha$-amilase.

c. Pembentukan Indol 
Uji indol bertujuan untuk menganalisis kemampuan isolat bakteri dalam memecah asam amino triptofan menjadi indol serta asam piruvat dan $\mathrm{NH}_{4}{ }^{+}$ (Lay, 1994). Berdasarkan hasil yang diperoleh, tidak ada satupun isolat bakteri lignoselulolitik saluran pencernaan rayap yang membentuk indol di akhir reaksi. Ini menunjukkan bahwa seluruh isolat bakteri tidak memiliki kemampuan dalam memecah triptofan menjadi asam piruvat. d. Uji katalase

Uji katalase bertujuan untuk melihat kemampuan isolat bakteri lignolitik pencernaan rayap dalam mereduksi $\mathrm{H}_{2} \mathrm{O}_{2}$ (Lay, 1994). Berdasarkkan hasil uji, didapatkan data bahwa seluruh isolat menunjukkan hasil positif yang ditandai dengan timbulnya gelembung udara pada

Tabel 3. Karakteri biokimia isolat bakteri lignoselulolitik pencernaan rayap (Isoptera: Rhinotermitidae dan Termitidae)

\begin{tabular}{|c|c|c|c|c|c|c|c|c|c|c|c|}
\hline \multirow[t]{2}{*}{ No } & \multirow[t]{2}{*}{ Uji Biokimiawi } & \multicolumn{10}{|c|}{ Isolat bakteri } \\
\hline & & $\mathbf{A}$ & D & 7 & 11.2 & 16 & 17 & 20 & 22 & 46 & 75 \\
\hline 1 & Fermentasi Glukosa & +++ & +++ & + & ++ & +++ & +++ & + & ++ & ++ & +++ \\
\hline 2 & Hidrolisis Pati & +++ & +++ & ++ & + & ++ & ++ & + & ++ & ++ & ++ \\
\hline 3 & Pembentukan Indol & - & - & - & - & - & - & - & - & - & - \\
\hline 4 & $\begin{array}{l}\text { Reduksi Hidrogen } \\
\text { Peroksida }\left(\mathrm{H}_{2} \mathrm{O}_{2} \quad 30 \%\right) / \\
\text { Uji Katalase }\end{array}$ & + & + & +++ & ++ & + & +++ & + & +++ & +++ & ++ \\
\hline 5 & Reduksi Nitrat & + & + & +++ & + & + & + & ++ & + & + & + \\
\hline
\end{tabular}

Keterangan: +++: kuat, ++: sedang, + lemah, -: tidak ada

kultur setelah ditetesi hidrogen peroksida. Timbulnya gelembung-gelembung udara pada uji katalase mengindikasikan adanya aktivitas katalase yang dihasilkan oleh bakteri sehingga mampu mengubah hidrogen peroksida menjadi air dan oksigen (Lay, 1994).

\section{e. Reduksi Nitrat}

Uji reduksi nitrat adalah uji yang dilakukan untuk melihat kemampuan bakteri dalam mereduksi nitrat menjadi nitrit atau senyawa sederhana lainnya. Berdasarkan hasil yang diperleh, diketahui bahwa seluruh isolat bakteri lignolitik pencernaan rayap menunjukkan hasil yang positif, ditandai dengan perubahan warna medium menjadi merah. Isolat bakteri yang menunjukkan aktivitas tertinggi secara kualitatif terlihat pada isolat bakteri 7 diikuti bakteri 20, selebihnya menunjukkan aktivitas reduksi nitrat yang lebih rendah (Tabel 3).

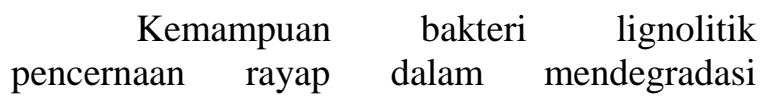

biopolimer nitrogen dan melepaskan amonia, melibatkan reaksi enzimatik sehingga dapat mengubah nitrat menjadi nitrit. Beberapa bakteri diketahui memiliki kemampuan untuk menggunakan nitrat sebagai satu-satunya sumber karbon. Pada bakteri saluran pencernaan rayap, umumnya memiliki peran dalam aktivitas fiksasi nitrogen sehingga bakteri ini berpotensi memiliki aktivitas nitrogenase. Brauman et al., (2015) dalam Muwawa et al., (2016) menunjukkan bahwa mikrobiota usus rayap bertanggung jawab atas fiksasi nitrogen di dalam usus rayap.

\section{Kesimpulan}

Berdasarkan penelitian yang telah dilakukan, dapat ditarik beberapa kesimpulan, yakni: Sepuluh isolat bakteri lignoselulolitik saluran pencernaan rayap (Isoptera: Rhinotermitidae dan Termitidae) merupakan bakteri dengan pertumbuhan fakultatif anaerob, memiliki karakter morfologi yang hampir serupa, 
dengan bentuk koloni meliputi irregular dan filamentous, tepi koloni berupa lobate, undulate, dan filamentous, serta warna koloni berupa putih sampai putih kekuningan. Hasil pengecatan gram menunjukkan bahwa sebagian besar bakteri adalah bakteri gram positif dengan sel bakteri berbentuk coccus dan bacil. Analisis biokimiawi menunjukkan bahwa bakteri ini memiliki kemampuan dalam fermentasi glukosa, hidrolisis pati, reduksi hidrogen peroksida $\left(\mathrm{H}_{2} \mathrm{O}_{2} \quad 30 \%\right)$ dan mereduksi nitrat.

\section{Ucapan Terima Kasih}

Peneliti berterimakasih kepada Fakultas Biologi Universitas Gadjah Mada yang memfasilitas Laboratorium untuk pelaksanaan penelitian ini, serta Kementrian Keuangan RI melalui dana LPDP yang mendukung berjalannya penelitian ini.

\section{Referensi}

Auer, L., Lazuka A., Sillam-Dussès D.., Miambi E, O'Donohue M., \& Hernandez-Raquet G. (2017). Uncovering the Potential of Termite Gut Microbiome for Lignocellulose Bioconversion in Anaerobic Batch Bioreactors. Front. Microbiol. 8:2623. DOI: 10.3389/fmicb.2017.02623

Begum, K., Mannan, S.J., Rezwan, R., Mahinur, M., Rahman, M.M., Rahman, M.S., \& Kamlal, A. N.E. (2017). Isolation and Characterization of Bacteria with Biochemical and Pharmacological Importance from Soil Samples of Dhaka City. Dhaka Univ. J. Pharm. Sci. 16(1): 130.

Brauman, A., Majeed M.Z., Buatois B., Robert A., Pablo A-L, \& Miambi E., (2015). Nitrous Oxide (N2O) Emissions by Termites: Does the Feeding Guild Matter. PloS ONE. 10(12):0144-340. DOI: 10.1371/journal.pone.0144340

Brune, A. (2014). Symbiotic digestion of lignocellulose in termite guts. Nature Reviews Microbiology, 12(3), 168-180. DOI: $10.1038 /$ nrmicro3182
Devaraj, V. \& Kasti, S.S. (2019). Isolation and Molecular Characterization of Termite Gut Microflora. Int. J. Sci. Res. in Biological Sciencesl. 6(3): 41-49 DOI: DOI:10.26438/ijsrbs/v6i3.4149

Ferbiyanto, A., Rusmana I., \& Raffiudin, R. (2015). Characterization and Identification of Cellulolytic Bacteria from gut of Worker Macrotermes gilvus. HAYATI Journal of Biosciences. 22 (2015) 197200. DOI:10.1016/j.hjb.2015.07.001

Hussain, T., Roohi, A., Munir, S., Ahmad, I., Khan, J., hermann, V.E., Kim, K.Y., \& Anees, M. (2013). Biochemical characterization and identification of bacterial strains isolated from drinking water sources of Kohat, Pakistan. African Journal of Microbiology Research. 7(16): 1581-1582

Lay, B.W. (1994). Analisis Mikroba di Laboratorium. Rajawali Press. Jakarta

Lazuka, A., Auer L., O’Donohue M., \& Hernandez- Raquet, G. (2018). Anaerobic lignocellulolytic microbial consortium derived from termite gut: enrichment, lignocellulose degradation and community dynamics. Biotechnol Biofuels, 11:284 DOI: 10.1186/s13068-018-1282-x

Liang, L., Song, X., Kong, J., Shen, C., Huang, T., \& Hu, Z. (2014). Anaerobic biodegradation of high-molecular-weight polycyclic aromatic hydrocarbons by a facultative anaerobe Pseudomonas sp. JP1. Biodegradation 25, 825-833. DOI: 10.1007/s10532-014-9702-5

Lima, Thâmarah de Albuquerque, Pontual, E.V., Dornelles, L.P., Amorim, P.K., Sá, K.A., Coelho, L.C.B.B., Napoleão, T.H., \& Paiva, P.M.G. (2014). Digestive enzymes from workers and soldiers of termite Nasutitermes corniger. Comparative Biochemistry and Physiology, Part B. 176:1-8. DOI: 10.1016/j.cbpb.2014.07.001 
Mannan, S.J., Rezwan, R., Rahman, M.S., \& Begum, K. (2017). Isolation and Biochemical Characterization of Lactobacillus species from Yogurt and Cheese samples in Dhaka Metropolitan Area. Bangladesh Pharmaceutical Journal. 20(1): 28

Masai, E., Ichimura A., Sato Y., Miyauchi K., Katayama Y., \& Fukuda, M. (2003). Roles of the enantioselective glutathione $\mathrm{S}$ transferases in cleavage of $\beta$-aryl ether. $J$ Bacteriol 185(6):1768-1775. DOI: $10.1128 / J B .185 .6 .1768-1775.2003$

Molina-Guijarro, J.M., Pérez-Torres J., MuñozDorado J., Guillén-Carretero F., Moya L.R., Cutuli M.H., \& Fernández M.E.A. (2009). Detoxification of azo dyes by a novel $\mathrm{pH}$-versatile, salt-resistant laccase from Streptomyces ipomoea. Int Microbiol 12:13-21. DOI: 10.2436/20.1501.01.77

Mulyani, P.D. (2021). Isolasi dan Karakterisasi Lignoselulase Bakteri Saluran Pencernaan Rayap (Isoptera: Rhinotermitidae dan Termitidae) (Tesis). Universitas Gadjah Mada. Yogyakarta.

Muwawa, E.M., Budambula N.L.M., Osiemo Z.L., Boga H.I., \& Makonde H.M. (2016). Isolation and characterization of some gut microbial symbionts from funguscultivating termites (Macrotermes and Odontotermes spp.). African Journal of Microbiology Research. 10 (26): 9941004. DOI: 10.5897/AJMR2016.8060

Nasehi, M., Torbatinejad N.M., Zerehdaran S., \& Safaei, A.R. (2014). Effect of (Pleurotus florida) Fungi on chemical composition and rumen degradability of wheat and barley straw. Iranian $j$ appl anim sci 4(2):257- 261

Pukhrambam, N. (2019). Comparison of original gram stain and its modification in the gingival plaque samples. $J$ Bacteriol Mycol Open Access. 7(1):1-3. DOI: 10.15406/jbmoa.2019.07.00231
Suryono, P., Finna, P., Wahyu, P.N., \& Aulia, A. (2019). Isolation and Identification of Bacteria and Actinomycetes Isolated from Wilting Banana Plants (Musa Sp.). IOP Conference Series: Materials Science and Engineering. 532(2019): 3. DOI: $10.1088 / 1757-899 X / 532 / 1 / 012028$

Taylor, B.F. (1983). Aerobic and anaerobic catabolism of vanillic acid and some other methoxy-aromatic compounds by Pseudomonas sp. strain PN-1. Appl. Environ. Microbiol. 46, 1286-1292. DOI: 10.1128/aem.46.6.1286-1292.1983

Wenzel M., Schonig M., Berchtold M., Kampfer P., \& Konig H. (2002). Aerobic and facultatively anaerobic cellulolytic bacteria from the gut of termite Zootermopsis angusticollis. J App Microbiol 92:32-40. DOI: 10.1046/j.13652672.2002.01502.x

Sakolvaree, J., \& Deevong, P., (2016). Isolation and Characterization of cellulase producingbacteria from the gut of a Higher Termite, Termes propinquus. The 5th Burapha University International Conference "Harmonization of Knowledge towards the Betterment of Society"193-203.

Stieglmeier, M., Wirth R., Kminek G., \& MoisslEichinger C. (2009). Cultivation of Anaerobic and Facultatively Anaerobic Bacteria from Spacecraft-Associated Clean Rooms. Applied and Environmental Microbiology, 75(11). 3484-3491. DOI:10.1128/AEM.02565-08

Zhou, J., Duan, J., Gao, M., Wang, Y., Wang, X., \& Zhao, K. (2018). Diversity, Roles, and Biotechnological Applications of Symbiotic Microorganisms in the Gut of Termite. Current Microbiology. 76:755761 DOI: $10.1007 / \mathrm{s} 00284-018-1502-4$ 